\title{
Bruten vithet: om den ryska femininitetens sinnliga och temporala villkor
}

\author{
Lönn, Maria \\ Stockholm: Leopard Förlag 2018 \\ 315 sider. ISBN 9789188647030
}

Omtalt av Tatiana Wara [Førsteamanuensis i pedagogikk, Høgskulen på Vestlandet (HVL), tatiana.wara@hvl.no]

Denne boken bygger på Maria Lönn sin doktorgradsavhandling, skrevet som en antologi presentert i ni kapitler. Introduksjonskapittelet gir både en kort innføring til det teoretiske tilfanget i boka og redegjør for bokens samfunnsaktuelle tematikk. Med utgangspunkt i et kjønnskritisk perspektiv har boken en spennende tilnærming til hvordan kjønnede vilkår for hvit femininitet blir artikulert og tolket. Boken handler også om hvordan strukturelle ideer og forestillinger om kultur, klasse, modernitet og temporalitet er legemliggjort gjennom kropp og sensualitet.

Bakgrunnen for prosjektet er rasistiske fordommer mot russiske kvinner $i$ en Stockholm-kontekst. Bokens ambisjon, slik Lönn argumenterer, er å skrive fram kompleksitet og variasjoner av hvit russisk feminitet. Forfatteren skriver selv at boken kan leses som et forsøk på å fange opp det kulturelle imaginære ved feminitet, giennom dimensjonene tid, rom, sanser og kropp.

Boken starter med en anekdote som kontekstualiserer svensk offentlig samtidsdiskurs og som situerer russiske kvinner "etter» de demokratiske og progressive svenske kvinnene. Russiske kvinner blir framstilt som utdaterte, umoderne og seksualiserte "andre». Russisk utseende blir til synlige kroppstegn som knyttes til noe «ikke-svensk». Boken skriver seg inn i diskursen om hierarkiske forhold mellom siviliserte trendy vestlige og tradisjonelle, primitive østlige moderniteter. Gjennom å undersøke representasjoner av «hvit russisk feminitet» i ulike geografiske kontekster, stiller forfatteren seg kritisk til antagelsen om de polariserte grensene mellom øst og vest. Å bli identifisert som russisk eller som en kvinne fra øst marginaliserer hvit russisk feminitet, argumenterer Lönn.

Det empiriske materialet i denne studien er basert på feltarbeid og intervjuer med 23 russiskfødte middelklassekvinner (født mellom 1970-1990) i Stockholm, St. Petersburg og Moskva. Alle kvinnene jobber på en eller annen måte med mote. 
Motens funksjon er ifølge Lönn å definere «hva som er i tiden» og «hva som går ut av tiden» og blir dermed et perspektiv for å få tilgang til den førkroppslige og fenomenologiske dimensjonen av modernitet. Ifølge henne åpner hvit russisk feminitet opp for en analyse av «rasifierad modernitet» og hierarkier av hvithet. I tråd med kritiske hvithetsstudier, har forfatteren operasjonalisert «hvithet» som en form for privilegium. Med utgangspunkt i perspektiv på hvithet diskuteres marginaliseringspraksiser som overordner noen og underordner «de andre» i møte med kjønn, etnisitet, geografisk tilhørighet og sosial klasse. Gjennom fokuset på moteorienterte hvite russiske kvinner fra tre ulike byer, belyses ikke bare det kjønnede sosiokulturelle vilkåret for hvit feminitet, men også hvordan politikk og geografisk tilhørighet virker inn, bryter og bekrefter, konstruerer og rekonstruerer vilkår for hvit feminitet.

Forfatteren har et fenomenologisk perspektiv på hvithet inspirert av den franske filosofen Maurice Merleau-Ponty. Lönn tar avstand fra en forståelse av hvithet som et gitt fenomen, og ser heller hvithet som perseptuell orientering. Perseptuell orientering handler ifølge Lönn om å leve og å møte verden gjennom kroppen. Den perseptuelle orienteringen former vår persepsjon, kroppsskjema og vår forståelse av sosiale kategorier. Disse perspektivene utvikles og reflekteres i lys av blant annet Sara Ahmed, Iris Marion Young, Gilles Deleuze, Frantz Fanon, Donna Haraway og Linda Martín Alcoff. Fokus settes på hvordan komplekse, asymmetriske maktkonstruksjoner og ideer om modernitet, rase, feminitet og klasse konstituerer vilkår for hvithet. Det argumenteres overbevisende for disse teoretiske kombinasjonene. En av styrkene til boken er dette brede teoretiske tilfanget og det velbegrunnede perspektivet på hvithet, som forfatteren oversetter til praktisk analyse av hvordan hvit feminitet brytes og bekreftes i møte med majoritet, modernitet og sosial klasse. De velvalgte teoriene belyser det empiriske materialet på god måte og gir rom for originale tolkninger av hvordan kroppslige grenser markeres og opprettholdes gjennom alle kroppens sanser.

Lönn bruker "sensorisk metode» som baseres på at datamaterialet også inkluderer emosjonelle og psykologiske elementer. I den forbindelsen poengterer forfatteren at man under et sensorisk feltarbeid må være oppmerksom på sine egne, altså forskernes, sanseutrykk, reaksjoner og fordommer. Dette er etter min mening underutviklet i analysen. En kunne forvente at en som bygger avhandlingen sin på fenomenologisk sensorisk feltarbeid i større grad ville beskrive samspill, spenninger og nyanser som oppstår i møte med informantene. Det hadde vært en fordel om forfatteren kunne skrevet mer eksplisitt om sin egen deltagelse i kunnskapsproduksjonen. Denne metodologien gir forfatteren, og ikke minst hennes informanter, ulike roller i forskningsprosjektet, med forskjellig grad av involvering og medforskerposisjon. Det er uklart for leseren hvilken status de ulike informantene har. Det gis også få opplysninger om disse kvinnenes livssituasjon, noe som giør det vanskelig å forholde seg til de praksistyper og habitus kvinnene tar med seg når vi ikke kjenner til de kontekster hvor disse er utviklet. Alt i alt er boken teoretisk nyttig og et kreativt bidrag til studier om Russland, migrasjonsforskning, kjønnsforskning og kritisk hvithetsforskning. 